\title{
The Convergence of Law: The Diversity of Discourses
}

\author{
Andrey Y. Mordovcev \\ Vladivostok State University of Economics and Service
}

Tatyana V. Mordovceva

Taganrog Institute of management and economics

Aleksey Y. Mamychev

Vladivostok State University of Economics and Service Email: eldirect@mail.ru, aum.07@mail.ru

\section{Doi:10.5901/mjss.2015.v6n3p262}

\section{Abstract}

The problem of understanding of the essence of the convergence of law is always in one or another form observed in the Western and Russian legal science. Converging process always had an objective basis of its origin and development, was determining the content and features of the development of many national legal institutions, and also norms and principles of international law. Today, the convergence of law takes place in the framework of political and economic globalization, which, of course, stimulates the interest of researchers to this multidimensional phenomenon. Of a particular interest in this aspect are mixed legal systems, the research of which is conducted in the framework of the theory of legal convergence and has a high level of complexity due to the inevitable involvement of a wide range of different factors. The impacts of various factors, contributing to the convergence of the Romano-Germanic and Anglo-Saxon law are taking place, processes of "infiltration" of law institution are happening at the regional level and so on. The article covers key aspects of the evolution of the discourses of convergence of law from the Ancient to modern theories of mixed legal systems. The author's findings are of great importance for the development of the theory of law, comparative law and political science at the beginning of XXI centuary.

Keywords: convergence of law, legal framework, mixed jurisdictions, legal doctrine.

\section{Introduction}

Unfortunately, in the Soviet social science in 60-80-ies the western theory of convergence (in the legal and political variant of this theoretical and practical education) immediately received so called "registration" in the scientific officiality, and naturally, here took place its ideological reading, and as a result it was considered to be «bourgeois» $n$ «antiMarxist».

Convergence in the Soviet humanitarian discourse was limited mainly to the sharp criticism of the possibilities of approachment of the socialist and capitalist worlds, the acquisition of similar traits and characteristics. This kind of interpretation was develop also in monographic studies of those years, in dictionary articles and academic literature (M. Dictionary, 2013).

"The theory of convergence (from lat. converge - converge) - socio-philosophical and political concept, according to which the internationalization of economic, political, cultural activity and the presence of some common structural and functional aspects of industrial society... bring to approach of politically and socially divergent systems - capitalism and socialism with the possibility of their merging in the future in mixed society, synthesizing a positive side of each of them" (Modern Western philosophy, http://elar.urfu.ru/handle/10995/971., 2013).

At the turn of XX-XXI centuries, researchers have already gone from the data-ideological understanding of the nature of convergence in general and legal convergence in particular and consider the essential aspects of this phenomenon and process in the other dimensions. In particular, many Western legal scholars draw attention to the fact that any "update", "edit" or "modernization" of legal norms and institutions, disturbing during the coming convergence of individual elements of the national legal system, as well as different legal systems always has risk-causing character (V.V. Palmer, 2011): causes in legal practice different law-making, law enforcement and law - interpretative risks, 
especially in the so-called "mixed jurisdictions" (W. Tetlly, 2012).

In this respect, it is no coincidence that the theory of convergence in the XX century became one of the main concepts of modern Western jurisprudence, political science, sociology, Economics, and has had a significant impact on comparative legal studies, in many ways, extending their subject and the theoretical and methodological base.

\section{Literature Review}

\subsection{Antique approach}

Turning to the historical aspects of convergence in the legal field it should be noted that in the ancient world, the notion of "convergence" was absent, however, beginning with Plato, different philosophical theories were built, in which the content and meaning of this concept was discussed at an intuitive level. In particular, Plato in his most recent work "Laws" laid the philosophical and legal foundations of interest of subsequent European thinkers to the problem of political-legal "heterogeneity", the question about the nature, objective or subjective nature of the converging processes at the earliest age of Western civilization. In general - theoretical terms, ancient Greek thought was moving in the direction of the search for political and legal ideals ("right form"), but eventually went on thinking of the state and legal realities.

Aristotle, staying, of course, in the same philosophical and legal traditions, goes even further in understanding the importance of converging processes in politics and law. His state-legal ideal, as it is known, is a mixed model of organization of public authorities. "Political system as a whole is not a democracy and oligarchy, but is the average between them, it is called politija... So better is the judgment of those who mixes several kinds, because that political system, which is a combination of many species, is really the best" (Aristotle, http://publ.lib.ru/ARCHIVES/A/ ARISTOTEL'/_Aristotel'.html, 2012).

For the Romans the universe no longer seems being endless, it is narrowed to the limits of the state, and the Imperial society, on the contrary, is extended to the scale of the Cosmos, which, of course, already plays an important existential-philosophical premise in relation to the occurrence of legal-converging processes.

\subsection{West European Middle Ages}

The formation of national states and legal systems of Western Europe in the period of decay of the Roman Empire and later are closely involved with multidisciplinary and polivector converging processes, approaches and synthesis of the most different in their nature methods and forms of norm - forming legal systems. Christianity in this period was a special spiritual basis for converging-acculturating state and legal processes. Legal norms and institutions of various Christian Nations are beginning to converge, slowly, but still happens their particular synthesis, on the basis of the new European Christian philosophy and world vision.

The first result of legal convergence in the framework of this social-spiritual (permeated with biblical precepts, ideas about Last Judgment and standards of Christian ethics) paradigm was, of course, the reception of Roman law, the institutions of which did not immediately replace from the Western regulatory space the feudal customary law and neutralized available in the early middle Ages desire to build a Christian nation on "Apostolic pattern". It is clear that all these processes occurred only after a very long and complicated converging phase.

«To build a society based on Roman law, to take it for a sample - was it a violation of the divine law, search for justice for the account and at the expense of mercy?... Thomas Aquinas in the early XII century put an end to this criticism. His works, using the works of Aristotle and showing that pre-Christian philosophy based on mind, largely conformed to the divine law, has contributed to the "expulsion of devils" from Roman law" (R. David, Jean-Christophe Spinosi, http://sudru.com/, 2013).

\subsection{Modern Age}

So, for many centuries in Western political and legal space took place very tangible converging processes. However, their results did not become a "homogeneous" jurisdiction, was happening not a merger, but namely the harmonization of different legal forms, which of course did not go unnoticed by researchers of XVIII-XIX century.

In this regard, of course, are important works of CH. L. Montesquieu, in particular, significant in his creation work " On the spirit of laws", in which he justifies the value of empirical and social methods of legal research, has made a significant contribution to the definition of the subject of comparative law, as well as in the identification of evaluation criteria of objective, taking place in the global political-legal environment converging-divergence processes, and not "in 
general", at the level of some scientific and philosophical abstractions, but in relation to specific (and contemporary) states.

Montesquieu took into account "the nature of things" in the study of state legal institutions and structures arising from certain nations in a certain historical era, he noted the necessity of taking into account many climatic and cultural factors that affect various legal and political reception, determining the principles of interaction of national legal systems. He very carefully approached the analysis of the specifics of state-legal reality of different nations - Roman, Greek, French, African, Persian, English, Chinese and others.

In General, W. L. Montesquieu created an original context field for not only theoretical, but also practical understanding of the legal processes of convergence and divergence, as well as their results.

For example, he notes that "thanks to the Italian scientist the right of Justinian penetrated into France, where previously only the Code of Theodosius is known, as the laws of Justinian were drawn up after the settlement of the barbarians in Gaul. This law was met with some opposition; however, it was held contrary to the exclusions of the Popes, patronized their canons. The St. Louis tried to spread respect for him with the help of made in his possession translation of the books of Justinian..." (Ch.L. Montesquieu, http://www.livelib.ru/work/1000460404, 2011).

It is important that Ch. L. Montesquieu drew attention and showed clearly that the functional convergence of law (as well as political systems) is dialectical and includes regulatory, innovative, instrumental (varies tools of legal practice), communicative (creates new legal conditions of interaction of subjects of legal relations), prognostic features, however, at the same time converging processes can be of destabilizing and contentious character, i.e. adversely affect prevailing in a particular state and society the mechanism of maintaining the legal order and the preservation of the rule of law.

G.V.F. Hegel, obviously, did not in see motion, convergence of different national legal systems important to create, for example, a single Western legal space of expressions regarding changing (in his eyes) of the European world. Although, some converging legal aspect he saw in colonization, the main problem of which, in his opinion, was to underestimate the importance of full integration of the legal space of colonies and the mother countries. In particular, he wrote: "In the modern time the colonies were not given the same rights as the population of the metropolis; it has led to wars and in the end to the independence of the colonies, as evidenced by the history of the English and Spanish colonies" (G.V.F. Hegel, http://psylib.ukrweb.net/books/gegel03/index.htm, 2013).

\subsection{Convergence in Western doctrinal-legal state of XX century}

Generally, in the Western world of the twentieth century has developed a wide range of views on the nature and limits of political-legal and socio-economic convergence: from attempts to justify the inevitability of "assimilation" by capitalism the socialist countries, which must inevitably follow after the development of market economy, the democratization of the legal and political life, the liberalization of state legal regimes and subsequent rejection of ideological confrontation, to judgments based on some interpretation of the objective changes (O. Kononova and Z. Yakimova, 2013), taking place in both the political and legal systems (for example, the development of institutions of state-monopoly regulation and planning of socio-economic life in several Western states, a joint decision of the socialist and capitalist states of a number of important human tasks, and so on).

In this respect, is not a coincidence that at about the same time, among some representatives of Western legal and political science the idea of "negative convergence" is spreading (Marcuse, G., Habermas Y. and others), according to which both socio-economic and politico-legal systems master from each other not so much positive as negative elements. (L. Kirsanova and O. Korotina, 2014).

\section{Methods and Materials}

Namely in XX the issues of convergence and divergence of legal systems get a new theoretical and methodological sound that largely is associated with increasing trends of convergence of the Romano-Germanic and Anglo-Saxon legal families, the convergence of which (in addition to the above situational pragmatic-utilitarian reasons), no doubt, is connected with the General history of the Protestant-Catholic Christian culture, relative proximity (while saving some logico-structural differences) of legal thinking, legal philosophy and basic ethical and legal values of legal practices, political ideologies in Western European and North American States, etc.

During this period it is possible to speak about the origin, mainly in Western legal and political discourses of several methodological directions of comprehension of the phenomenon of convergence of law:

1) systemic-functional;

2) cultural-anthropoligical; 
3) ploitical.

Namely this directions focus the attention of researchers on legal-doctrine, legal-practical (including the content and form of legal policy), state ideology and legal-cultural aspects of the problem.

\section{Results and Discussions}

Of particular interest in theoretical and in practical terms are mixed legal systems, a study of which is conducted in the framework of the theory of legal convergence and has a high level of complexity due to inevitable involvement of a wide range of very different (in fact legal, and political and social) factors.

In this case, fully justified is the fact that Western scholars, first of all, conduct a comprehensive analysis of such categories as "mixed legal system" and "mixed jurisdiction". Thus, W. Tetlly proposes to use the concept of "mixed jurisdiction" to mean "the country or territorial unit with mixed legal system" (W. Tetlly, 2012).

Generally, in modern Western legal literature, these concepts are often used interchangeably, and "mixed" refers to such a legal system in which the elements characteristic of different legal families, systems, traditions are absent or are mixed in a special way. In the framework of the theory of convergence namely mixed legal system, on the one hand, are the result of a convergence of different (relatives or not) legal worlds, and on the other, create the necessary framework, socio-legal preconditions for escalation of converging processes (not only in legal but also in the economic, political and cultural spheres of life).

As for the relationship between the concepts of "mixed legal system" and "mixed jurisdiction" in Western European and American literature have already gathered sufficient number of "doctrinal" material to the present time, because the conceptualization of this issue takes place already at the turn of XIX-XX centuries. In particular, F. P. Welton offers the following definition: "Mixed jurisdiction is a legal system in which the Romano-Germanic tradition was filled to some extent with Anglo-American law" (W. Tetlly, 2012). Much later, Evans-Jones R believes that the mixed legal system "to some extent demonstrates the characteristic features of both civil continental and English general law traditions" (Evans-Jones R., 2008).

Modern English comparatist Palmer V.V. in "Mixed jurisdictions worldwide: the third legal family" uses the category of "mixed jurisdiction" with the same meaning, namely the jurisdiction in which the common and civil law are the main components of legal doctrine" (V.V. Palmer, 2011). On the basis of this approach, as a rule, such mixed legal systems, as South Africa, Scotland, Louisiana, Quebec, the Philippines, Israel and other are distinguishing.

It should be noted that these (and many others) defenitions, in general, are very indicative for the traditional European understanding of mixed legal systems: in Western comparativistics the main focus has for a long time been done specifically on the result of the convergence of the Romano-Germanic right tradition and Anglo-American law, on the combination of their elements, which of course corresponds to objectively caused vector of development of political and legal processes in the second half of the XX century, however, the theoretical-methodological and practical positions does not correspond to the real situation and should be substantially revised.

In relation to the process of convergence of the Romano-Germanic and Anglo-Saxon law M. Marchenko proposes several groups of factors contributing, or vice versa, preventing their convergence.

So, as the primary factors of convergence of the Romano-Germanic and Anglo-Saxon law, should be considered "all that common - in the form of similar economics, social and political structure of society, the same type of machinery of government, legal culture, and other similar in nature and in potential orientation of the components, that unites these legal families" [9].

As primary factors, hindering the convergence of the Romano-Germanic and Anglo-Saxon law, it is necessary to identify and consider all that special - in the form of historical and national traditions, customs, peculiar to each legal family, and others similar in nature phenomena, institutions and establishments, - that separates the given legal family.

In general, the primary factors are the basis, which do not only determine the nature, internal structure and content of each of the two legal families, but also determines the nature and tendencies of development of relations between them, i.e., includes a specific evolutionary-functional component.

Secondary factors, of course, are derived from primary, express, or rather "reflect inherent in the RomanoGermanic and Anglo-Saxon legal families of the underlying potential and trends, as to their convergence and divergence.

Among the secondary factors - elements that contribute to the convergence of the legal families - should be allocated primarily those that occur at the regional level, the relationship and interaction of the Romano-Germanic and Anglo-Saxon law" (M. Marchenko, http://ukr-pravo.at.ua/Materialy/biblioteka/Evropeiskoe/marchenko_m_deryabina_e_ pravo_evropeyskogo_soyuza_voprosy_is.pdf, 2007).

Of course, the secondary factors that contribute to the convergence of these legal families, being in close 
connection with the primary factors, in particular are observed also at the global level (on the level of legal families) and at the local level (in relation to specific national legal systems). For example, in the legal system of the USA, where the legal system of Louisiana, being in nature and character of the Romano-Germanic phenomenon, is in direct connection with the Anglo-Saxon legal world.

Most clearly the nature of the impact of secondary factors contributing to the convergence of the RomanoGermanic and Anglo-Saxon law, as these factors themselves, are manifested at the regional level, in particular at the level of the European Union.

J. Beaston belives that soon after the accession of the UK to the European Union " The English law is increasingly began to resemble the European continental law, law of the European Union" (J. Beatson, 2010). Moreover, in his opinion, the influence of continental European law on English common law in the course of time does not only weaken, but on the contrary, even more increases as its development and improvement, as evidenced, in particular, numerous decisions of several institutions of the European Union, "coming from the traditions of the Romano-Germanic civil law" and directly related to British common law.

In general, at expansion of the legal regulation, which is implemented through the help of norms of the acts of the institutions of the European Union, the process of "Europeanization" of English law, the process of "infiltration" and adaptation of many of the norms and institutions of the European (continental) law in Anglo-Saxon (common) law are increasingly growing. (J. Beatson, 2010).

As a result, and under the influence of some other factors, according to some researchers, "English law is gradually becoming less English" (R. Cooke, 2008) in both practical and theoretical point of view. This meant, in particular, the fact that British membership in the European Union increasingly has an impact not only on law-making and enforcement activities of the relevant English authorities, but also on the traditional view of the English legal establishment, in particular, about the constitutional and municipal law. (V. Bognar, 2006).

Of great importance, among the factors contributing to the convergence of the Romano-Germanic and AngloSaxon law in the Western, mainly American literature, is such phenomenon, as Americanization, or reception of American, general in nature, rights in European continental law (W. Wiegand, 1991).

"Calling the reception of American law his great influence after the Second World War on European law, and in some cases, also on the right of other regions of the world, the authors with excessive exaggeration of the significance of this phenomenon, spend even some parallels between American reception and reception of Roman law" (M. Marchenko, http://ukr-

pravo.at.ua/Materialy/biblioteka/Evropeiskoe/marchenko_m_deryabina_e_pravo_evropeyskogo_soyuza_voprosy_is.pdf, 2007).

Overly exaggerating the influence of American law in the European in post-war, and even more in subsequent periods and without any reason, equating the "Americanization" of European law to the reception of Roman law, researchers, however, are right that the common law, represented by the American legal system has had a certain influence on the Romano-Germanic civil law.

\section{Conclusion}

The convergence of law is polivector process of rapprochement and interpenetration of the individual components of different national legal systems on the basis of the global socio-cultural, political and economic factors, the universal legal principles and standards, as well as the specifics of their implementation in domestic legal relations, the result of which is the internationalization and harmonization of the legal regulation of public relations.

The main converging risks at present are followings: a) approval of necessity of borrowing, by different civilizational nature states of legal institutions, ideals and images of Western civilization as a means of "saving" the world and overcome dangerous threats; b) the leveling of differences between national legal systems, which leads to narrowing and gradual elimination of own socio-cultural and spiritual foundations, to rejection of the principles of multiculturalism and pluralism in the public law sphere, and as a result - to protracted legal anomie; c) increasing trends of abolition of national sovereign states, the nature and function of which cease to be incurred (implemented) and operating within the national legal system of international legal subsystem and the challenges of the new world order".

The "mixed legal system" and "mixed jurisdiction" categories relate to each other as a whole and part, since the latter reflects predominantly publicly-power component of the national legal system, the specifics of the exercise of judicial power, the totality of the powers of other government structures for the resolution of various legal conflicts and cases of violations in a particular area, whereas under mixed should be understood the legal system, including a wide range of items specific to the different legal and political traditions, coexisting and interacting in a single mechanism of 
legal regulation of social relations.

\section{References}

Modern Western philosophy, 2013. Dictionary. M. http://elar.urfu.ru/handle/10995/971.

Palmer, V.V., 2011. Mixed Jurisdictions Worldwide: The Third Legal Family. C.U. Press.

Tetlly, W., 2012 Mixed Jurisdictions: Common Law vs. Civil Law // Louisiana Law Review.Vol.60.

Aristotle, 2012. Essays in four volumes. M., http://publ.lib.ru/ARCHIVES/A/ARISTOTEL'/_Aristotel'.html

David, R. and Jean-Christophe, S., 2013. Major legal systems of today. http://sudru.com/

Montesquieu, Ch. L., 2011. The spirit of laws. M., http://www.livelib.ru/work/1000460404

Hegel, G.V.F., 2013. Philosophy of law. M., http://psylib.ukrweb.net/books/gegel03/index.htm

Evans-Jones, R., 2008. Receptions of Law, Mixed Legal Systems and the Myth of the Genius of Scots Private Law // Law Quarterly Review. Vol. 114.

Marchenko, M., 2007. Convergence of the Romano-Germanic and Anglo-Saxon law. Kiev-Simferopol. http://ukr-pravo.at.ua/Materialy/ biblioteka/Evropeiskoe/marchenko_m_deryabina_e_pravo_evropeyskogo_soyuza_voprosy_is.pdf.

Beatson, J., 2010. Has the Common Law a Future? II The Cambridge Law Journal. 2010. Vol. 56. Part I.

Cooke, R., 2008. The Road Ahead for the Common Law II International and Comparative Law Quarterly. Vol. 53. Part 2.

Kirsanova, L. and Korotina, O., 2014. On the Contents of the Protest Conscience in Russia. Wolrd Applied Sciences Journal 31(5).

Kononova, O. and Yakimova Z., 2013. Competence as an object for Assessmen and Measuremen in Training Quality Control System//World Applied Sciences journale. Vol. 27.

Bognar, V., 2006. The British Constitution in the Twentieth Century. Oxford.

Wiegand, W., 1991. The Reception of American Law in Europe // The American Journal of Comparative Law. №2. 